\title{
Testamentary Trusts and Capricious Testators
}

\author{
Mark Pawlowski* \\ *Mark Pawlowski, School of Law, Maritime Greenwich Campus, University of Greenwich, \\ London, SE10 9LS, UK; Tel: +44(0) 208331 9463; Email: m.pawlowski@gre.ac.uk.
}

\begin{abstract}
The notion that a trust may fail because it serves no useful purpose, or reflects merely the whim or fancy of the testator, seems to fly in the face of testamentary freedom and, in particular, the testator's right to dispose of his estate in whatever manner he chooses ${ }^{1}$ subject only to the court's control over illegal or immoral conditions ${ }^{2}$ and the making of reasonable financial provision ${ }^{3}$ for his family and dependants. So how have the courts grappled with these two competing aspects of public policy? The tension between these two competing aspects of public policy forms the subject matter of this article.
\end{abstract}

\section{Introduction}

The only English authority, so far as the writer is aware, is Brown $v$ Burdett, ${ }^{4}$ where the testatrix left her house to trustees upon trust to block up all the windows and doors in every room (except those in which she directed that a housekeeper and his wife should reside) for a period of 20 years and thereafter the property was to pass to the beneficiaries named in her will. The judgment, which expressly refers to the uselessness of the trust, highlights the fundamental question of whether it is open to a testator to divert (or even permanently exclude) property by his will from family and dependants purely on a whim, or on the basis of some eccentric notions of vanity and self-expression. Where to draw the line between what is, and what is not, acceptable may not be an easy question to question for the courts, especially if the amount at stake is not great and the period of diversion or exclusion is only temporary or limited.

\footnotetext{
${ }^{1}$ See, Blathwayt v Baron Cawley [1976] AC 397, at 426, per Lord Wilberforce.

${ }^{2}$ Conditions restricting alienation, restraining the freedom of marriage, encouraging separation or divorce, or interfering with the exercise of parental responsibilities, are void as being contrary to public policy.

${ }^{3}$ See, the Inheritance (Provision for Family and Dependants) Act 1975.

${ }^{4}$ (1882) 21 Ch D 667.
} 


\section{Scottish case law}

In M'Caig's Trustees $v$ Kirk-Session of the United Free Church of Lismore, ${ }^{5}$ the testatrix ordered 11 bronze statues to be erected (at a cost of $£ 1,000$ each) to honour her parents and their nine children, including herself, in a large circular tower built in the form of an amphitheatre on a hill in Oban. It was made clear that the public would have no access to the tower and there was no living family who might take pleasure from viewing the statues. Moreover, it was envisaged that the cost of maintaining the monument would come out of the income of the estate, which effectively meant that it would be at least eight years before the beneficiaries under the will could take their inheritance.

Not surprisingly, the court struck down the provision as being a "sheer waste of money" 6 having no reason and benefitting no one except (perhaps) those connected with the carrying out of the intended work. Moreover, with one exception, none of the persons whose statues were being proposed to be erected were prominent public or historical figures, nor did they have any connection with the town of Oban or the surrounding area, so as to justify that their memory should be perpetuated in this way.

A similar case (also dealing with the M'Caig family) is M'Caig $v$ University of Glasgow, ${ }^{7}$ decided a few years earlier, involving a perpetual trust to construct stone statues (and artistic towers) in the likeness of the testator, his brothers, sisters, and his father and mother, at a cost of $£ 1,000$ each, at various prominent points on his estates in Oban. The object, although intended by the testator to encourage young and rising Scottish artists, was characterised by Lord Kyllachy as having "no utility, private or public" and "perpetuating at great cost, and in an absurd manner, the idiosyncracies of an eccentric testator". ${ }^{8}$ Lord Justice Clerk also referred to the useless nature of the direction and, in particular, to the fact that none of the residents of Oban would benefit from the memorials. ${ }^{9}$

Another case is Aitken's Trustees $v$ Aitken, ${ }^{10}$ where the instruction to build a massive equestrian statue of the testator in bronze (at a cost of £5,000) was struck out as being "unreasonable, extravagant and useless". ${ }^{11}$ Indeed, the instruction would have involved the destruction of a valuable rent-producing property in the middle of a town without any recognised benefit to the inhabitants. The municipality itself was opposed to the project and passed a resolution stating that it was a "fantastic proposition".

Two other cases call for comment. In Lindsay's Executor v Forsyth, ${ }^{12}$ a sum of $£ 1,000$ was placed on trust to apply the income in putting fresh flowers once a week on the graves of the testatrix and her mother. In expressing this wish, the testatrix was seeking to carry on a practice which she herself had carried out of placing flowers every week on her mother's grave. Two members of the court (Lords Aitchison and Mackay) characterised the direction as "extravagant" given the large amount involved and the fact that the income was to be

\footnotetext{
${ }^{5}$ [1915] SC 426.

${ }^{6} \mathrm{Ibid}$, at 434, per Lord Salvesen.

7 [1907] SC 231.

8 lbid, at 242.

${ }^{9}$ Ibid, at 240.

10 [1927] SC 374.

$11 \mathrm{Ibid}$, at 385, per Lord Blackburn.

12 [1940] SC 568.
} 
applied in perpetuity. In Mackintosh's Judicial Factor v Lord Advocate, ${ }^{13}$ the object of the trust was to erect a granite vault in order to contain the testatrix's own remains and those of two persons who had predeceased her by many years. Her whole estate, amounting to $£ 3,600$, was to be used for this purpose which included the exhumation of the two people (who were unrelated to her) and their re-internment in the vault together with her own remains. Significantly, the testatrix had died without any family and the two persons concerned were the only two people with whom she had had any kind of connection and whom she knew as her uncle and aunt. Lord Fleming concluded that "there is no reason for this being done except to gratify the deceased's desire to have a rather grandiose monument built to perpetuate her memory and the memory of these relatives". ${ }^{14}$ In his view, therefore, the trust had no social or economic purpose justifying the expenditure of such a large sum of money.

What these cases, therefore, reveal is essentially an exclusionary policy which rejects a testamentary gift which is manifestly wasteful of resources judged against the court's ostensibly objective standard of what is unacceptable. The upshot is that legal acceptability is measured in terms of what is perceived to have financial advantage to the testator's beneficiaries or have wider social benefit or utility to the community.

\section{Commonwealth and American approach}

An interesting Canadian case is The Estate of Clive Wishart, decided by the Court of Queen's Bench of New Brunswick, in September 1992. The testator's will directed that the executors should have "my horses shot by the Royal Canadian Mounted Police and then buried." The horses had been the testator's pets and it was apparent that he had been concerned with their welfare and did not want them abused after his death. Riordon $\mathbf{J}$ concluded that the destruction of four healthy horses for no useful purpose should not be upheld and, accordingly, held that the direction in the will was void. The upshot was that the horses resulted to the residuary beneficiaries named in the will.

A number of American cases are also instructive. In Eyerman v Mercantile Trust, ${ }^{15}$ the testatrix had instructed her executor "to cause our home . . . to be razed and to sell the land". The Missouri Court of Appeals refused to allow the destruction of the house (worth $\$ 40,000$ ) on the grounds that the object was entirely capricious and against public policy in so far as it contemplated a "senseless" waste and destruction of resources. Apart from harm to the neighbours, the destruction would have caused a considerable monetary loss to the estate (the demolition would reduce the value of the land to \$650.00) with no apparent reason or benefit to the testatrix or her family. In Will of Pace,${ }^{16}$ the testamentary trust required the trustee to destroy certain houses and maintain the property as unused vacant lots. The trust was held to violate public policy against waste and the New York Surrogate Court ordered the trustee to sell the houses without restriction.

\footnotetext{
${ }^{13}[1935]$ SC 406.

${ }^{14} \mathrm{Ibid}$, at 414-415.

${ }^{15} 524$ SW 2d 210 (1975).

${ }^{16} 400$ NYS $2 d 488$.
} 
In Re Scott's Will, Board of Commissioners of Rice County v Scott, ${ }^{17}$ the testator's direction was even more extreme, namely, to destroy all of the residue of the money (including cash and evidences of credit) belonging to the deceased's estate to the obvious disadvantage of the testator's family and dependents. Not surprisingly, the Supreme Court of Minnesota held that the direction was void. In some cases, the testator, rather than destroy property, may wish to have a valuable object (such as jewellery) buried with them. ${ }^{18}$

Unwarranted restrictions on the use of estate property, as opposed to their outright destruction, have also been struck down on similar principles of wastefulness and harm to individuals or community. In Colonial Trust $v$ Brown, ${ }^{19}$ the relevant direction provided for a restriction on the construction of a building more than three stories in height and forbidding leases for a term of more than one year. The land in question was located in a prime financial and retail business district and there was evidence that the restriction would be detrimental to the growth and development of the area. On this basis (and in the absence of any obvious benefit to anyone), the restriction (which was unlimited in duration) was held to be invalid. The court was particularly influenced by the fact that the restriction, if allowed to stand, would make it impossible for the estate to receive a proper rental income from the property or, indeed, to obtain suitable tenants. This was seen as being detrimental not only to the interests of the beneficiaries of the trust but also, more widely, to neighbouring property owners.

There are also two Australian cases worthy of comment. In Re Headrick's Will, ${ }^{20}$ the testatrix left instructions in her will that, if the local council did not accept the use of her land for a park and sports ground, the trustees were to have her house (and other improvements) on the land demolished and the proceeds of sale of the land were to fall into residue. Stanley J held that the direction to demolish was invalid and not binding on the trustees on public policy grounds which prevented the wasteful destruction of valuable housing. In Re Boning, ${ }^{21}$ the testator left his house to trustees, for a period of 20 years, with the condition that all animals and birds on the property were to be left undisturbed, the water supply, electricity and telephone services were to be disconnected, and the house was to be secured by locks and kept in a secure state. No repair or maintenance was to be carried out, unless required by law. After 20 years, the property was to be sold and the proceeds paid to Greenpeace Australia Ltd on condition that the money was used for its international activities. The testator's obvious intention was to exclude all human occupation from the property and allow it to revert to a natural state. White $\mathrm{J}$ held that the trust was, clearly, for a capricious purpose notwithstanding the absence of any next of kin who would have been denied an inheritance as a result of the testator's desire to stagnate the property for 20 years.

\footnotetext{
1788 Minn 386, 93 NW 109 (1903), Supreme Court of Minnesota.

${ }^{18}$ See, for example, Re Meksras Estate 63 Pa D \& C $2^{\text {nd }} 371$, (1974), (testatrix's wish to be buried with her jewellery held void).

${ }^{19} 105$ Conn 261, 135A 155 (1926).

20 [1953] QWN 23.

${ }^{21}$ [1997] 2 Qd R 12, Supreme Court of Queensland.
} 


\section{Rationale for striking out capricious purposes}

The foregoing analysis suggests that, whilst the courts are reluctant to interfere with the expressed wishes of a testator, public policy will prohibit any testamentary disposition which, though not illegal or immoral (in the sense of contravening any statute or the general law) may prove entirely wasteful of the testator's assets. One rationale for the court's intervention is evident from the Scottish and American cases. Whilst the testator is alive, the law assumes that he is unlikely to embark upon wasteful expenditure (although, ultimately, this is a matter of his own choice), but, upon death, there is nothing to inhibit his extravagance or folly except discretionary control by the courts. Coupled with this approach is the notion that the testator, once dead, no longer faces the repercussions of his actions and so may wash his hands of his family without suffering the censure that a living person would bear for such behaviour. On this reasoning, the testator's wishes are treated as capricious because this is not something he would have done whilst alive.

Whilst this certainly provides one explanation for the court's intervention, the more obvious rationale is the court's reluctance to sanction the extravagant consumption of valuable estate assets when this is shown to be detrimental to the interests of others, whether this be the testator's beneficiaries or the community generally. The courts, therefore, embark on a detailed analysis of the facts of each case, in particular, the amount of expenditure involved, the social utility of the testator's project, any perceived harm to the community and length of time the beneficiaries under the will are kept away from their legacies, in weighing up whether to uphold the testator's wishes or condemn them as unacceptable. This is not limited necessarily to the erection of statues or memorials to the testator for his (or her) own personal gratification, but may also include perverse directions to have funds administered in an inherently risky or unprofitable investment such as a failing family business.

Where the direction involves the actual destruction of the testator's assets, as opposed to merely their wasteful expenditure, the testator's wishes are more likely to be characterised as a senseless reduction of the testator's estate. This is because the asset in question is treated as having economic value and utility (whether, for example, it be a house or the testator's pets) and, hence, its deliberate destruction without rational purpose is seen as not only objectively harmful to the interests of the beneficiaries but also (in some cases) detrimental to society generally and, therefore, prohibited on public policy grounds. Here again, however, the testator's motives for destroying an item of property (for example, the private diary or personal papers of a well-known politician or celebrity) may be entirely justified in the circumstances of a particular case, regardless of value, in order, for example, to preserve their confidentiality or avoid personal embarrassment.

The same rationale is applied where the direction involves, not the wasteful expenditure or destruction of property, but its management or upkeep in a capricious manner. Here again, the period of diversion or exclusion may be an important factor, especially if the asset is a family home or other valuable commodity. In the absence, therefore, of any evidence of discernible benefit, the direction may be struck down as an uneconomic and extravagant 
deployment of resources both in a communal sense and as an unwarranted impairment of the beneficiaries' economic rights.

\section{Conclusion}

The underlying rationale for the court's intervention in cases involving trusts for capricious purposes is the law's primary desire to protect the general economic interests of testate beneficiaries and/or the community against the "dead-hand" of the irrational or capricious testator. Understood in this way, the rule against capricious purposes has an important role to play in modern trust law in requiring a normative standard of rationality in the enforcement of testamentary trusts which restricts testamentary freedom where the testator's expression involves an extravagant or wasteful use of estate property which is manifestly harmful to others.

Mark Pawlowski is a Barrister and Professor of Property Law in the School of Law, University of Greenwich, London, UK. Email: m.pawlowski@gre.ac.uk; http://gre.ac.uk/law./ 